\title{
A healthy start: promoting mental health and well-being in the early primary school years
}

\author{
Carmel Cefai $^{\mathrm{a} *}$ and Liberato Camilleri ${ }^{\mathrm{b}}$ \\ ${ }^{a}$ Department of Psychology, University of Malta, Msida, Malta; ${ }^{b}$ Department of Statistics and \\ Operations Research, University of Malta, Msida, Malta
}

\begin{abstract}
Mental health problems in children represent a significant international health concern, with up to one in five children using mental health services during the course of any given year. Identifying the processes of what prevents social, emotional and behaviour difficulties (SEBD) and promotes healthy development from an early age can make a significant contribution to the promotion of positive mental health in children. This article describes a longitudinal study which sought to identify the risk and promotive factors as young children move from the early to junior years in primary school. Multilevel analysis was used to identify the individual, classroom, school, home and community factors that predict change in SEBD and in prosocial behaviour in the early school years. It also calculated the cumulative effect of the various risk and promotive factors on the pupils' well-being and mental health. The article presents the windows of vulnerability and opportunity for young children's healthy development, proposing a trajectory for healthy development in early and middle childhood.
\end{abstract}

Keywords: prosocial behaviour; risk factors; promotive factors; SEBD; mental health; multilevel analysis

\section{Introduction}

About $20 \%$ of school children experience social, emotional and behaviour difficulties (SEBD) such as ADHD, behaviour problems, anxiety and depression, during the course of any given year and may need the use of mental health services (Centre for Disease Control and Prevention 2013; WHO 2011). The figure may rise to 50\% amongst children coming from social disadvantaged areas such as urban regions (Adelman and Taylor 2010). Children with SEBD are usually the least liked and understood students (Avramadis and Norwich 2002; Baker 2005; Kalambouka et al. 2007), the least likely to receive effective and timely support (Kalambouka et al. 2007; Ofsted 2007), and the most vulnerable to school failure and premature school leaving, social exclusion, and mental health problems (Cole, Daniels, and Visser 2005; Colman et al. 2009; Fergusson, Horwood, and Ridder 2005). They are more at risk of engaging in such behaviours as substance abuse, violence and criminality, and to leave school without any certification or vocational skills, with consequent poor employability opportunities (Bradley, Doolittle, and Bartolotta 2008; Colman et al. 2009; Fergusson, Horwood, and Ridder 2005). The high incidence of SEBD among these children (Parsons et al. 2001; O'Regan 2011) indicates that in the case of SEBD, schools in general tend to be more willing to consider exclusion as a legitimate resolution, than is the case for other forms of special educational needs (SEN), making SEBD the only SEN category which exposes the student to

*Corresponding author. Email: carmel.cefai@um.edu.mt 
increased risk of exclusion as a function of its identification (Jull 2008). In a review of studies on the voices of students with SEBD, Cefai and Cooper (2010) provide a portrait of students who feel unloved and unwanted by their teachers, victims of an unjust and oppressive system, unsupported in their needs and excluded from the academic and social aspects of everyday life.

The erstwhile simplistic mono-causal explanations for SEBD has shifted towards the more complex and multi-factorial understandings and explanations, and SEBD is now seen as a dynamic, multi-layered phenomenon that results from a wide range of influence that coalesce to create an increasingly cumulative effect (Cooper and Jacobs 2011). Numerous studies have sought to identify the risk and protective factors for difficulties experienced by children and young people in their development, such as delinquency and substance use, at multiple levels of the social environment, including the individual, the peer group, the school, the family and the community (Arthur et al. 2007; Hawkins, Catalano, and Arthur 2002; Stoddard, Zimmerman, and Bauermeister 2012; Youngblade et al. 2007). Many of these studies however, have been largely focused on adolescents, on such behaviours as substance use and delinquency, and on single rather multiple contexts, while few examined both risk and promotive factors in such contexts, taking into consideration both behaviour problems and prosocial behaviour. Rather than construing mental health as a unidimensional phenomenon, with psychological problems and wellbeing as opposite states on the same dimension, multicomponent models of mental health and well-being suggest that SEBD and well-being are separate, even if related, phenomena, with both having an independent effect on social and academic outcomes (Furlong et al. 2011; Renshaw 2014).. Strength-based approaches such as educational resilience, positive youth development, and positive psychology amongst others, underline the need for proactive strategies which strengthen and promote children's healthy development and, thereby, seek to prevent difficulties from developing in the first place, by making use of the children's strengths and assets while providing enabling and protective contexts, such as the home and school systems (e.g. Furlong et al. 2011; Guerra and Bradshaw 2008; Masten 2001; Seligman et al. 2009; Werner and Smith 1992; Youngblade et al. 2007). In seeking to understand and predict mental health in children, we thus need to consider both risk and positive factors and how these interact to promote healthy development and protect children from the risks they may be exposed to in their development.

Research has also underlined the need for longitudinal studies which map the trajectory of children's development from an early age as they move from early years to primary school and then to secondary school. Such studies are very useful to understand better the relationship between predictive factors and well-being and mental health (Chanfreau et al. 2013). SEBD is starting earlier in primary school (Farrell and Humphrey 2009; Rose et al. 2009), and the onset at an early age is a predictor of social and academic difficulties in adolescence (Fergusson, Horwood, and Ridder 2005; Rose et al. 2009). Farrell and Polat (2003) argue that while children who are formally identified by local educational authorities as having SEBD tend to be nine-years-old or above, it is clear that many of these children have been identified as having such problems well before they were formally assessed, as early as the first year in primary school. This underlines the need for early identification and consequent early intervention before difficulties become more serious and entrenched in children's behaviour patterns (DataPrev Project 2011; Domitrovich, Cortes, and Greenberg 2007; National Institute for Health and Clinical Excellence 2008).

This article presents the findings of a longitudinal study carried out in the early primary school years as it sought to map the trajectory of young school children from 
the early years to the junior primary school years. In contrast to much of the previous research, this study examines multiple factors - individual, school and home and community - related to both SEBD and to positive behaviour in this pathway, seeking to identify both risk and promotive factors. It construes the child situated within multiple layers or systems, with each layer having an impact on the child's behaviour, learning and development (Bronfenbrenner 1989), and it will make use of hierarchical multilevel analysis, which was used to identify the significant predictors of SEBD and prosocial behaviour, at individual, classroom and whole levels. Rather than focusing on one specific behaviour, it examines both internalized and externalized behaviour problems as well as prosocial behaviour. It also delineates the cumulative effect of risk and promotive factors on the mental health of primary school children.

Using data from an SEBD national project together with other data collected three years later, the study examined the drivers of change, both positive and negative, from Year 1 (six-year-olds) to Year 4 (nine-year-olds) in primary schools. More specifically the study sought to identify the factors which predicted an increase in SEBD and in prosocial behaviour from Year 1 to Year 4, and which of these were the strongest predictors, making use of hierarchical multilevel analysis. The study also examined the cumulative effect of risk and promotive factors on mental health in the early years of schooling.

\section{Methodology}

\section{Sample}

The present study is a three year follow up of 486 nine-year-old pupils who participated in the first phase when they were six-years-old (Year 1 primary school). The students were selected randomly from 56 state and non-state primary schools in Malta ensuring a good geographical representation of the student population. The sample comprised 232 male and 254 female pupils, and the number of students selected from each school was proportional to the school size. The parents and classroom teachers of the selected students were also asked to participate by providing essential information about SEBD and prosocial behaviour together with other information related to individual pupils and to the class, school, home and community contexts. The follow up sample decreased to 448 pupils, with $92.2 \%$ of the original sample still participating in the second study, but this attrition rate did not have any significant impact on the representativeness of the sample in terms of gender, geographical region or school type. Consent from all those participating was sought prior to data collection, including the parents on behalf of their children.

\section{Instruments}

\section{Strengths and Difficulties Questionnaire}

The Maltese version of the Strengths and Difficulties Questionnaire (SDQ; Goodman 1997) was used as a measure of the students' SEBD as well as prosocial behaviour and was completed by the students' teachers and parents. The SDQ is a brief questionnaire which has been used by many researchers as a screening tool to measure SEBD and prosocial behaviour, and identifies the prevalence of mental health difficulties among children and young people. The Maltese SDQ has correlation coefficients ranging from 0.72 to 0.89 (teachers) and from 0.71 to 0.83 (parents) on the five subscales, suggesting a satisfactory level of construct validity, while the Cronbach's Alpha assessing test-retest reliability ranged from 0.67 to 0.92 for individual items, and from 0.75 to 0.89 for the five 
subscales, suggesting satisfactory reliability at both individual and subscale levels (Cefai et al. 2011).

\section{Supplementary questionnaires}

The study construes child behaviour as being influenced by multiple contexts in line with Bronfenbrenner's systems theory (Bronfenbrenner 1989). The classroom, the whole school, the family, the local community, as well as the child's own individual characteristics, all impact his or her behaviour. The predictive variables of SEBD and prosocial behaviour were categorised into individual, home and community, and whole class and whole school factors (cf. Arthur et al. 2007; Cefai, Cooper, and Camilleri 2009; Hawkins, Catalano, and Arthur 2002). The individual student variables were grouped into two subsets, namely individual characteristics such as gender, locality and language, and classroom/school variables such as academic progress and expectations, engagement and relationships (Table 1). It was hypothesized that these factors will be related to SEBD and prosocial behaviour at the negative and positive ends respectively.

The questionnaires drew on various other studies and scales on risk and protective factors in SEBD and prosocial behaviour, but in view of the broad based study which included both SEBD and prosocial behaviour at individual, home, school and class factors, it was decided to construct a questionnaire which was more in line with the objectives of the study as well as the local context, since all the existing questionnaires were based on international contexts. Use was made of the questionnaires used in an earlier study on which the present one is based and which had examined various individual, school and home factors related to SEBD and prosocial behaviour (Cefai, Cooper, and Camilleri 2009). The present questionnaires were also based on a careful reading of the literature on risk and protective factors, including existing scales and questionnaires, to ensure that the items represented as valid construction of the multilevel factors related to SEBD and prosocial behaviour as possible, while taking into account the local context as well, including the findings of an earlier study.

Three questionnaires were constructed, one for teachers, one for pupils and one for parents respectively. The teachers' questionnaire was divided in three sections, one on individual pupils (learning and behaviour), one on the classroom variables, and the other on the whole school variables. The parents' questionnaire had two sections, one on the individual child variables (home-related variables), and the other on the family and community variables. The pupil questionnaire explored the pupils' views on their own learning, behaviour, and relationships. Information about individual student variables was extracted from teachers', pupils' and parents' questionnaires; the parents' questionnaire provided information about home and community variables, while the teachers' questionnaire examined whole class and school variables (see Table 1).

Individual student variables included demographic variables such as gender, mother tongue, locality, illness or disability and medication, from the parents' questionnaires, while information on communications skills, self-esteem and self-efficacy was collected from both the teachers' and parents' questionnaires (e.g. the child's self-esteem: low, moderate, high). Data on the pupils' academic and social behaviour at school was obtained from the teachers' questionnaire, with questions on academic progress, engagement, learning difficulties and academic support, academic expectations, and support with school work, as well as information on repeating, attendance, classroom relationships, friends at school, play with peers, as well as teacher-parent communication. Questions/ 
Table 1. Individual, school, home and community variables.

\begin{tabular}{|c|c|c|}
\hline Individual variables & $\begin{array}{l}\text { Home and community } \\
\text { variables }\end{array}$ & Whole Class variables \\
\hline Gender & Family structure & Pupils' participation in lessons \\
\hline Mother tongue & Family size & Pupils' involvement in \\
\hline Locality & Fathers' and mothers' & decisions \\
\hline Illness or disability & occupations & Pupils' collaboration in learning \\
\hline Medication or therapy & Fathers' and mothers' & Pupils' behaviour during play \\
\hline Communication & educations & Pupils' sense of classroom \\
\hline $\begin{array}{l}\text { Self-esteem (teacher/parent } \\
\text { reported) }\end{array}$ & $\begin{array}{l}\text { Family income } \\
\text { Family time }\end{array}$ & $\begin{array}{l}\text { Community } \\
\text { Classroom resources }\end{array}$ \\
\hline $\begin{array}{l}\text { Self-efficacy (teacher/parent } \\
\text { reported) }\end{array}$ & $\begin{array}{l}\text { Behaviour at home } \\
\text { Communication with }\end{array}$ & $\begin{array}{l}\text { Classroom management } \\
\text { Teacher training }\end{array}$ \\
\hline $\begin{array}{l}\text { Academic progress (teacher/pupil } \\
\text { reported) }\end{array}$ & $\begin{array}{l}\text { parents } \\
\text { Relationships with siblings }\end{array}$ & $\begin{array}{l}\text { Whole school variables } \\
\text { Pupils' behaviour at school }\end{array}$ \\
\hline Teacher academic expectation & Relationships with relatives & Pupils' support and \\
\hline Parent academic expectation & Parent reported friends & collaboration \\
\hline Learning difficulties & Source of support at home & Pupils' engagement in school \\
\hline $\begin{array}{l}\text { Learning support (teacher/pupil } \\
\text { reported) }\end{array}$ & $\begin{array}{l}\text { Membership in } \\
\text { organisations }\end{array}$ & $\begin{array}{l}\text { activities } \\
\text { Pupils' participation in }\end{array}$ \\
\hline Peer support with work & Participation in & decisions \\
\hline Support with homework & organisations & Bullying \\
\hline Source of support at school & Family cohesion & Staff participation in school \\
\hline Repeating a year & Family conflict & activities \\
\hline $\begin{array}{l}\text { Engagement (teacher/pupil } \\
\text { reported) }\end{array}$ & $\begin{array}{l}\text { Parenting stress } \\
\text { Parenting difficulty }\end{array}$ & $\begin{array}{l}\text { Staff participation in decisions } \\
\text { Staff teamwork }\end{array}$ \\
\hline What helps in learning & Parenting quality time & Staff support and collegiality \\
\hline Attendance & Parenting supervision & Administrative support \\
\hline Teacher-parent communication & Parenting strategies & \\
\hline Parent-school communication & Neighbourhood safety & \\
\hline Teacher-pupils relationship & Neighbourhood support & \\
\hline Pupils-teacher relationship & & \\
\hline $\begin{array}{l}\text { Relation with peers (teacher/pupil } \\
\text { reported) }\end{array}$ & & \\
\hline Friends at school & & \\
\hline Close friends at school & & \\
\hline Support from close friends & & \\
\hline Plays with peers & & \\
\hline $\begin{array}{l}\text { Ways of improving behaviour at } \\
\text { school }\end{array}$ & & \\
\hline
\end{tabular}

Source: Adi et al. 2007; Arthur et al. 2007; Battistich, Schaps, and Wilson 2004; Baumeister et al. 2003; Bradley and Corwyn 2007; Darling 1999; Davies-Kean 2005; Engle and Black 2008; Desforges and Abouchaar 2003; Ford et al. 2007; Griffin et al. 2000; Gutman and Brown 2008; Gutman and Feinstein 2008; Hamre and Pianta 2001; Hawkins, Catalano, and Arthur 2002; Hysing et al. 2007; Leventhal and Brooks-Gunn 2000; Linnenbrink and Pintrich 2003; Loeber and Hay 1997; McLanahan 2009; McLaughlin, 2006; Rose et al. 2009.

statements had three response items, one positive, one medium/average, one negative, e.g. pupils' academic potential: high, average, poor; friends at school: a good number, a few friends, no friends; attendance: regular, irregular, mostly absent). Pupils also filled a number of questions on whether they have friends and whether their friends support them with their work and play with them. Similarly, parents completed a couple of questions related to parental academic expectations, support with homework and homeschool collaboration. Information on variables related to the family and community, was extracted from the parents' questionnaire. These included questions on the individual 
child, such as the child's behaviour at home, relationship with parents, siblings, relatives and friends; questions on the family's structure and relationships, such as two- or singleparent families, family size, parental occupation and education, family income, as well as family cohesion and conflict, parenting stress, difficulty, supervision and quality time, and a final section on neighbourhood safety and support. The relational variables were again measured on a three-point scale, e.g. family conflict: frequent, occasional, rare; parenting stress: high, average, low. We deliberated at length whether to include sensitive items related to family relationships such as violence and abuse in family in view of their strong relationship to SEBD. On the advice of various heads of school and the ethics committee, particularly in view of the small size of the island where proximity decreases anonymity and where everyone knows everyone else, we finally decided not to include such sensitive issues as these would have seriously compromised parental and consequently children's participation; moreover, if included it would have been unlikely that the responses would have been authentic. Nevertheless, this constitutes a limitation of the study and we will explore possible ways of going round this issue in the next phase of the study.

Whole class and whole school variables were based on the teachers' questionnaire which asked questions on the pupils' engagement and collaboration in learning, involvement in decision-making, sense of community, and behaviour and play, as well as classroom resources and teacher education. The whole school variables included pupils' behaviour, bullying, support, collaboration, and participation in decision-making, staff's participation in school activities, participation in decisions, teamwork and collegiality, as well as administrative support. Answers/statements were again answered on a three-point scale, e.g. pupils' sense of classroom community: strong, medium, weak; bullying at school: frequent, occasional, rare; staff collegiality: high, average, low.

The questionnaires were not a scale measuring latent variables, but consisted of varying types of questions measuring independent explanatory variables, ranging from demographic variables (nominal scale), factual questions (metric scale) and simple statements (ordinal scale mostly measured on a three-point scale). In the fitted multilevel models, these categorical variables were used as predictors to explain variation in the change of SEBD and prosocial scores. Each of the three questionnaires was piloted on a small group of teachers, pupils and parents respectively.

\section{Data analysis}

Multilevel analysis was used to identify the significant predictors of SEBD and prosocial behaviour, and rank them by their contribution in explaining variations in the responses at individual, classroom and whole levels. These predictors have been called risk and promotive factors (Furlong et al. 2011), with risk factors related to SEBD, and factors related to positive behaviour in the face of low risk called promotive factors. To identify the risk and the promotive factors that predict change in SEBD and in prosocial behaviour respectively, two scores were generated for each pupil by subtracting the Year $1 \mathrm{SEBD} /$ prosocial score from the Year 4 scores for teachers' and parents' evaluations separately. A positive change in the SEBD scores indicated an increase in social, emotional, and behaviour difficulties, while a positive change in the prosocial scores indicated an improvement in positive behaviour during the early primary school years.

Given the hierarchical structure of the data, where pupils are nested in classrooms and classes are nested in schools, modelling was carried out through multilevel analysis. A number of three-level random intercept models, using the Generalized Linear Latent and Mixed Models routine, were applied to relate the longitudinal change in the SEBD/ 
prosocial scores to each individual, classroom and school predictor, using teachers' and parents' evaluations separately. To assess the contribution of a predictor in a model, the log-likelihood of a one-predictor model is compared to the log-likelihood of the unconditional model, which includes no predictors. Explanatory variables that reduce the loglikelihood by a large degree, are strong predictors of the response variable. Besides estimating the contribution of each predictor in explaining variation in the responses, multilevel models also measure intraclass correlation coefficients which gauge the similarity of observed responses within classroom and school clusters.

\section{Findings}

\section{Risk factors}

The average change in SEBD scores from Year 1 to Year 4, provided by teachers (1.15) and parents $(0.48)$ are both positive, indicating that both groups of respondents perceive that pupils' difficulties increased during the early primary school years.

Multilevel analysis using teachers' evaluations identified 14 dominant risk factors that predict a significant increase in SEBD scores. Table 2 shows that eight of these predictors are individual variables mostly related to behaviour, relationships and learning; three are home and community variables, two whole school variables and the last one is a whole classroom variable. Bullying, pupil's communication skills and relationship with the teacher, family structure, and gender are some of the strongest predictors of SEBD.

Multilevel analysis using parents' evaluations identified 15 dominant risk factors that predict a significant increase in SEBD scores. Table 2 shows that seven of these predictors are individual variables mostly related to behaviour, relationships and learning; six are home and community variables, one is a whole classroom variable and another a whole school variable. The best discriminant predictor is gender, followed by bullying, child's behaviour at home, parental academic expectations, child support from close friends, family structure and parenting stress. These are then followed by poor classroom engagement, low selfefficacy and poor communication skills, and poor relationships with the teacher.

Table 3 displays the variances and intra-class correlations for each model at the student, classroom and school levels. The student level 1 variance dominates each model, however some risk factors account for a substantial part of the level 2 and level 3 variances, justifying the use of multilevel models. In the unconditional model (teachers' evaluations), the size of the variance component at student level (14.176) is around three times the size of the variance component at classroom level (4.978) and about four times the size of the variance component at school level (3.715). Some risk factors, mainly bullying at school, poor communication skills and poor relationship with teacher and peers, explain a substantial portion of the total variability in the change of SEBD scores during the three-year period. In the parents' evaluations model, the size of the variance component at student level (8.755) is around four times the size of the variance component at classroom level (2.116) and about seven times the size of the variance component at school level (1.352).

\section{Promotive factors}

The average change in prosocial behaviour scores provided by teachers $(0.18)$ and parents (0.32) respectively, are both positive, indicating that teachers and parents perceive that children tend to marginally improve their prosocial behaviour between Year 1 and Year 4. 
Table 2. Log-likelihood, change in deviance and p-values of significant SEBD predictors.

\begin{tabular}{|c|c|c|c|c|}
\hline Risk Factors & $\begin{array}{c}\text { Log- } \\
\text { likelihood }\end{array}$ & $\begin{array}{l}\text { Change in } \\
\text { deviance }\end{array}$ & $\begin{array}{l}\text { Degrees of } \\
\text { freedom }\end{array}$ & P-value \\
\hline \multicolumn{5}{|l|}{ Teachers' Evaluations } \\
\hline None (Unconditional model) & 1131.307 & 1 & & \\
\hline Bullying at school & 1122.631 & 17.352 & 2 & 0.000 \\
\hline Poor communication skills & 1123.572 & 15.470 & 2 & 0.000 \\
\hline Poor teacher-pupil relationship & 1124.361 & 13.892 & 2 & 0.001 \\
\hline Single-parent family & 1125.910 & 10.794 & 1 & 0.001 \\
\hline Gender (female) & 1126.352 & 9.910 & 1 & 0.002 \\
\hline Poor relationship with peers & 1125.118 & 12.378 & 2 & 0.002 \\
\hline No friends at school & 1125.593 & 11.428 & 2 & 0.003 \\
\hline Poor behaviour at school & 1126.343 & 9.928 & 2 & 0.007 \\
\hline Little participation in lessons & 1126.618 & 9.378 & 2 & 0.009 \\
\hline High parenting stress & 1127.146 & 8.322 & 2 & 0.016 \\
\hline Low self-esteem & 1127.349 & 7.916 & 2 & 0.019 \\
\hline $\begin{array}{l}\text { Poor teacher-parent } \\
\text { communication }\end{array}$ & 1127.763 & 7.088 & 2 & 0.029 \\
\hline Poor academic progress & 1128.014 & 6.586 & 2 & 0.037 \\
\hline $\begin{array}{l}\text { Little participation in } \\
\text { organizations }\end{array}$ & 1128.280 & 6.054 & 2 & 0.048 \\
\hline \multicolumn{5}{|l|}{ Parents' Evaluation } \\
\hline None (Unconditional model) & 703.548 & l & & \\
\hline Gender (male) & 694.331 & 14.434 & 1 & 0.000 \\
\hline Bullying at school & 695.468 & 16.160 & 2 & 0.000 \\
\hline Poor behaviour at home & 696.328 & 14.440 & 2 & 0.001 \\
\hline Poor academic expectation & 697.116 & 12.864 & 2 & 0.002 \\
\hline No support from close friends & 697.429 & 12.238 & 2 & 0.002 \\
\hline Single-parent family & 699.002 & 9.092 & 1 & 0.003 \\
\hline High parenting stress & 698.003 & 11.090 & 2 & 0.004 \\
\hline Little participation in lessons & 698.257 & 10.582 & 2 & 0.005 \\
\hline Low self-efficacy & 698.761 & 9.574 & 2 & 0.008 \\
\hline Poor engagement & 699.235 & 8.626 & 2 & 0.013 \\
\hline Poor communication skills & 699.481 & 8.134 & 2 & 0.017 \\
\hline Poor pupil-teacher relationship & 699.613 & 7.870 & 2 & 0.020 \\
\hline $\begin{array}{l}\text { Little participation in } \\
\text { organisations }\end{array}$ & 699.897 & 7.302 & 2 & 0.026 \\
\hline Poor communication with parents & 700.052 & 6.992 & 2 & 0.030 \\
\hline Poor parenting supervision & 700.497 & 6.102 & 2 & 0.047 \\
\hline
\end{tabular}

Multilevel analysis using teachers' evaluations identified 14 dominant promotive factors related to an improvement in prosocial behaviour in the early school years. Table 4 shows that eight of these predictors are individual variables mostly related to behaviour, relationships and learning; two are home and community variables, and two each are whole classroom and whole school variables respectively. The best predictor of a change in the pupil's prosocial behaviour over time is pupil's relationship with peers, followed by good relationship with the teacher, low level of bullying at school, high selfesteem and self-efficacy, and engagement in classroom activities.

Multilevel analysis using parents' evaluations identified 14 dominant promotive factors that improve prosocial behaviour during the early Primary school years. Table 8 shows that six of these predictors are individual variables mostly related to behaviour, relationships and learning; five are home and community variables; two are whole school 
Table 3. Variances and intra-class correlations of student, classroom and school levels (SEBD predictors).

\begin{tabular}{|c|c|c|c|c|c|c|}
\hline \multirow[b]{2}{*}{ Risk Factors } & \multicolumn{2}{|c|}{ Student (level 1) } & \multicolumn{2}{|c|}{ Classroom (level 2) } & \multicolumn{2}{|c|}{ School (level 3) } \\
\hline & Variance & $\begin{array}{l}\text { Intra-class } \\
\text { correlation }\end{array}$ & Variance & $\begin{array}{l}\text { Intra-class } \\
\text { correlation }\end{array}$ & Variance & $\begin{array}{l}\text { Intra-class } \\
\text { correlation }\end{array}$ \\
\hline \multicolumn{7}{|l|}{ Teachers' Evaluations } \\
\hline $\begin{array}{l}\text { None (Unconditional } \\
\text { model) }\end{array}$ & 14.176 & 0.620 & 4.978 & 0.218 & 3.715 & 0.162 \\
\hline Bullying at school & 13.308 & 0.639 & 4.280 & 0.205 & 3.248 & 0.156 \\
\hline $\begin{array}{l}\text { Poor communication } \\
\text { skills }\end{array}$ & 13.562 & 0.645 & 4.261 & 0.203 & 3.211 & 0.153 \\
\hline $\begin{array}{l}\text { Poor teacher-pupil } \\
\text { relationship }\end{array}$ & 13.813 & 0.641 & 4.381 & 0.203 & 3.369 & 0.156 \\
\hline Single-parent family & 13.629 & 0.634 & 4.476 & 0.208 & 3.381 & 0.157 \\
\hline Gender (female) & 13.528 & 0.632 & 4.513 & 0.211 & 3.376 & 0.158 \\
\hline $\begin{array}{l}\text { Poor relationship } \\
\text { with peers }\end{array}$ & 13.727 & 0.634 & 4.479 & 0.207 & 3.459 & 0.160 \\
\hline No friends at school & 13.879 & 0.633 & 4.553 & 0.208 & 3.510 & 0.160 \\
\hline $\begin{array}{l}\text { Poor behaviour at } \\
\text { school }\end{array}$ & 13.926 & 0.632 & 4.627 & 0.210 & 3.493 & 0.158 \\
\hline $\begin{array}{l}\text { Little participation in } \\
\text { lessons }\end{array}$ & 13.855 & 0.634 & 4.589 & 0.210 & 3.403 & 0.156 \\
\hline High parenting stress & 13.973 & 0.629 & 4.613 & 0.208 & 3.611 & 0.163 \\
\hline Low self-esteem & 13.920 & 0.629 & 4.689 & 0.212 & 3.529 & 0.159 \\
\hline $\begin{array}{l}\text { Poor teacher-parent } \\
\text { communication }\end{array}$ & 14.016 & 0.626 & 4.718 & 0.211 & 3.654 & 0.163 \\
\hline $\begin{array}{l}\text { Poor academic } \\
\text { progress }\end{array}$ & 13.981 & 0.624 & 4.832 & 0.216 & 3.576 & 0.160 \\
\hline $\begin{array}{l}\text { Little participation in } \\
\text { organisations }\end{array}$ & 14.093 & 0.625 & 4.793 & 0.212 & 3.678 & 0.163 \\
\hline \multicolumn{7}{|l|}{ Parents' Evaluations } \\
\hline $\begin{array}{l}\text { None (Unconditional } \\
\text { model) }\end{array}$ & 8.755 & 0.716 & 2.116 & 0.173 & 1.352 & 0.111 \\
\hline Gender (male) & 7.966 & 0.763 & 1.588 & 0.152 & 0.891 & 0.085 \\
\hline Bullying at school & 8.035 & 0.756 & 1.692 & 0.159 & 0.900 & 0.085 \\
\hline $\begin{array}{l}\text { Poor behaviour at } \\
\text { home }\end{array}$ & 8.164 & 0.765 & 1.577 & 0.148 & 0.935 & 0.088 \\
\hline $\begin{array}{l}\text { Poor academic } \\
\text { expectation }\end{array}$ & 8.099 & 0.759 & 1.618 & 0.152 & 0.954 & 0.089 \\
\hline $\begin{array}{l}\text { No support from } \\
\text { close friends }\end{array}$ & 8.354 & 0.763 & 1.702 & 0.156 & 0.888 & 0.081 \\
\hline Single-parent family & 8.268 & 0.744 & 1.834 & 0.165 & 1.004 & 0.090 \\
\hline High parenting stress & 8.330 & 0.742 & 1.769 & 0.158 & 1.126 & 0.100 \\
\hline $\begin{array}{l}\text { Little participation in } \\
\text { lessons }\end{array}$ & 8.356 & 0.741 & 1.833 & 0.163 & 1.086 & 0.096 \\
\hline Low self-efficacy & 8.429 & 0.737 & 1.856 & 0.162 & 1.154 & 0.101 \\
\hline Poor engagement & 8.398 & 0.727 & 1.964 & 0.170 & 1.192 & 0.103 \\
\hline $\begin{array}{l}\text { Poor communication } \\
\text { skills }\end{array}$ & 8.551 & 0.742 & 1.879 & 0.163 & 1.099 & 0.095 \\
\hline $\begin{array}{l}\text { Poor pupil-teacher } \\
\text { relationship }\end{array}$ & 8.423 & 0.730 & 1.936 & 0.168 & 1.177 & 0.102 \\
\hline $\begin{array}{l}\text { Little participation in } \\
\text { organisations }\end{array}$ & 8.642 & 0.727 & 1.983 & 0.167 & 1.256 & 0.106 \\
\hline
\end{tabular}


Table 3. (Continued).

\begin{tabular}{lccccccccc}
\hline & \multicolumn{2}{c}{ Student (level 1) } & & \multicolumn{2}{c}{ Classroom (level 2) } & & \multicolumn{2}{c}{ School (level 3) } \\
\cline { 2 - 3 } Risk Factors & Variance & $\begin{array}{c}\text { Intra-class } \\
\text { correlation }\end{array}$ & & Variance & $\begin{array}{c}\text { Intra-class } \\
\text { correlation }\end{array}$ & & Variance & $\begin{array}{c}\text { Intra-class } \\
\text { correlation }\end{array}$ \\
\hline $\begin{array}{c}\text { Poor communication } \\
\text { with parents }\end{array}$ & 8.597 & 0.722 & & 2.011 & 0.169 & & 1.291 & 0.108 \\
$\begin{array}{c}\text { Poor parenting } \\
\text { supervision }\end{array}$ & 8.690 & 0.722 & & 2.061 & 0.171 & & 1.287 & 0.107 \\
\hline
\end{tabular}

Table 4. Log-likelihood, change in deviance and p-values of significant promotive predictors.

\begin{tabular}{|c|c|c|c|c|}
\hline Promotive Factors & Log-likelihood & $\begin{array}{l}\text { Change in } \\
\text { deviance }\end{array}$ & $\begin{array}{l}\text { Degrees of } \\
\text { freedom }\end{array}$ & P-value \\
\hline \multicolumn{5}{|l|}{ Teachers' Evaluations } \\
\hline None (Unconditional model) & 823.875 & l & & \\
\hline Good relationship with peers & 810.949 & 25.852 & 2 & 0.000 \\
\hline Good teacher-pupil relationship & 813.469 & 20.812 & 2 & 0.000 \\
\hline No bullying at school & 813.787 & 20.176 & 2 & 0.000 \\
\hline High self-esteem & 815.202 & 17.346 & 2 & 0.000 \\
\hline High self-efficacy & 817.724 & 12.302 & 2 & 0.002 \\
\hline High engagement & 817.835 & 12.080 & 2 & 0.002 \\
\hline Two-parent family & 819.505 & 8.740 & 1 & 0.003 \\
\hline Good communication skills & 818.937 & 9.876 & 2 & 0.007 \\
\hline Low family conflict & 819.694 & 8.362 & 2 & 0.015 \\
\hline Participation in lessons & 820.099 & 7.552 & 2 & 0.023 \\
\hline Support from close friends & 820.148 & 7.454 & 2 & 0.024 \\
\hline Engagement in school activities & 820.266 & 7.218 & 2 & 0.027 \\
\hline Adequate classroom resources & 820.583 & 6.584 & 2 & 0.037 \\
\hline Good teacher-parent communication & 820.684 & 6.382 & 2 & 0.041 \\
\hline \multicolumn{5}{|l|}{ Parents' Evaluations } \\
\hline None (Unconditional model) & 684.118 & l & & \\
\hline No bullying at school & 670.143 & 27.950 & 2 & 0.000 \\
\hline Good relationship with relatives & 672.535 & 23.166 & 1 & 0.000 \\
\hline Two-parent family & 673.698 & 20.840 & 1 & 0.000 \\
\hline High self-efficacy & 676.992 & 14.252 & 2 & 0.001 \\
\hline High family income & 678.368 & 11.500 & 2 & 0.003 \\
\hline High engagement & 679.259 & 9.718 & 2 & 0.008 \\
\hline Friends at school & 680.774 & 6.688 & 1 & 0.010 \\
\hline Low parenting stress & 679.643 & 8.950 & 2 & 0.011 \\
\hline Gender (female) & 681.242 & 5.752 & 1 & 0.016 \\
\hline Good communication skills & 680.116 & 8.004 & 2 & 0.018 \\
\hline Support from close friends & 680.349 & 7.538 & 2 & 0.023 \\
\hline Good communication with parents & 680.692 & 6.852 & 2 & 0.033 \\
\hline Sense of classroom community & 680.956 & 6.324 & 2 & 0.042 \\
\hline Engagement in school activities & 681.048 & 6.140 & 2 & 0.046 \\
\hline
\end{tabular}


variables and another is a classroom variable. According to parents' evaluations, the best discriminant predictor is bullying, followed by the child's positive relationship with relatives, a two-parent family, high self-efficacy and high family income.

Table 5 displays the variances and intra-class correlations for each model at the student, classroom and school levels. In the unconditional model (teachers' evaluations), the size of the variance component at student level (5.869) is around twice the size of the variance component at classroom level (2.983) and about six times the size of the variance component at school level (0.917). For the random coefficient model containing classroom resources as a sole main effect, the variance component at the student level (5.836) is almost equal to the corresponding random component in the unconditional model; however the variance component at the classroom level (2.246) and school level (0.363) are considerably lower. This implies that classroom resources explain a large portion of the random variation in the change of prosocial behaviour scores at classroom and school levels, but hardly explains any of the random variation at student level.

The size of the variance component (parents' evaluations) at student level (3.451) is around twice the size of the variance component at classroom level (1.131) and is about six times the size of the variance component at school level (0.584). Some fixed effects, mainly bullying at school, child's relationship with relatives and friends, family structure, family income and child's self-esteem and self-efficacy explain a large portion of the total variability in the change of prosocial behaviour scores. Engagement in school activities and sense of classroom community explain a large portion of the random variation in the differences between prosocial scores at classroom and school levels, but hardly explain any of the random variation at student level.

\section{The cumulative effect of risk and promotive factors}

The study also examined the cumulative effect of the identified risk and promotive predictors on the pupils' mental health. For each pupil, the number of risk factors was counted from the list of significant predictors, and pupils were then grouped into categories according to the numbers of risk factors they were exposed to. Gender was excluded since teachers' and parents' evaluations suggested opposite trends. For all the other risk factors, teachers and parents shared similar views about which categories of the individual-, classroom-, school-, home- and community-related factors predicted an increase in SEBD. In $33.3 \%$ of the sample, no risk factor was present; one risk factor was present in $30.7 \%$ of the participants, two risk factors in $20.7 \%$, three in $9.3 \%$, four in $3.3 \%$ and five in $2.7 \%$.

In order to predict the pupil's likelihood of mental health difficulties on the basis of the number of risk factors, the information provided by the teacher- and parent-reported SDQ total difficulties and impact scores was combined by means of a computerised algorithm (Goodman, Renfrew, and Mullick 2000). The algorithm estimates the likelihood that mental health problems are 'unlikely', 'possible' or 'probable'. Table 6 shows the percentage of pupils within each level of mental health problems, grouped by the number of risk factors present. It is evident that the percentage of possible and probable mental health problems rises steadily with every additional risk factor $\left\{X^{2}(10)=25.05\right.$, $p=0.005\}$. The percentage of pupils showing at least signs of mental health problems (possible and probable outcome in the SDQ algorithm) is $12 \%$ in the group without any risk factors, increasing to $17.4 \%$ when one risk factor is present and $32.2 \%$ for two risk factors. The risk of mental health difficulty continues to increase significantly once pupils are exposed to more risk factors, ranging from $50 \%$ for pupils with three risk factors to 
Table 5. Variances and intra-class correlations of student, classroom and school levels

\begin{tabular}{|c|c|c|c|c|c|c|}
\hline \multirow[b]{2}{*}{ Promotive Factors } & \multicolumn{2}{|c|}{ Student (level-1) } & \multicolumn{2}{|c|}{ Classroom (level-2) } & \multicolumn{2}{|c|}{ School (level-3) } \\
\hline & Variance & $\begin{array}{l}\text { Intra-class } \\
\text { correlation }\end{array}$ & Variance & $\begin{array}{l}\text { Intra-class } \\
\text { correlation }\end{array}$ & Variance & $\begin{array}{l}\text { Intra-class } \\
\text { correlation }\end{array}$ \\
\hline \multicolumn{7}{|l|}{ Teachers' Evaluations } \\
\hline $\begin{array}{l}\text { None (Unconditional } \\
\text { model) }\end{array}$ & 5.869 & 0.601 & 2.983 & 0.305 & 0.917 & 0.094 \\
\hline $\begin{array}{l}\text { Good relationship } \\
\text { with peers }\end{array}$ & 5.152 & 0.678 & 2.123 & 0.279 & 0.321 & 0.042 \\
\hline $\begin{array}{l}\text { Good teacher-pupil } \\
\text { relationship }\end{array}$ & 5.229 & 0.663 & 2.187 & 0.278 & 0.465 & 0.059 \\
\hline No bullying at school & 5.326 & 0.673 & 2.270 & 0.287 & 0.316 & 0.040 \\
\hline High self-esteem & 5.248 & 0.627 & 2.472 & 0.296 & 0.645 & 0.077 \\
\hline High self-efficacy & 5.416 & 0.642 & 2.439 & 0.289 & 0.579 & 0.069 \\
\hline High engagement & 5.423 & 0.633 & 2.561 & 0.299 & 0.580 & 0.068 \\
\hline Two-parent family & 5.319 & 0.615 & 2.618 & 0.303 & 0.716 & 0.083 \\
\hline $\begin{array}{l}\text { Good communication } \\
\text { skills }\end{array}$ & 5.387 & 0.637 & 2.534 & 0.299 & 0.541 & 0.064 \\
\hline Low family conflict & 5.369 & 0.611 & 2.736 & 0.311 & 0.687 & 0.078 \\
\hline $\begin{array}{l}\text { Active participation } \\
\text { in lessons }\end{array}$ & 5.663 & 0.623 & 2.781 & 0.306 & 0.649 & 0.071 \\
\hline $\begin{array}{l}\text { Support from close } \\
\text { friends }\end{array}$ & 5.523 & 0.637 & 2.683 & 0.310 & 0.457 & 0.053 \\
\hline $\begin{array}{l}\text { Engagement in } \\
\text { school activities }\end{array}$ & 5.743 & 0.634 & 2.643 & 0.292 & 0.674 & 0.074 \\
\hline $\begin{array}{l}\text { Adequate classroom } \\
\text { resources }\end{array}$ & 5.836 & 0.691 & 2.246 & 0.266 & 0.363 & 0.043 \\
\hline $\begin{array}{l}\text { Good teacher-parent } \\
\text { communication }\end{array}$ & 5.501 & 0.616 & 2.716 & 0.304 & 0.716 & 0.080 \\
\hline \multicolumn{7}{|l|}{ Parents' Evaluations } \\
\hline $\begin{array}{l}\text { None (Unconditional } \\
\text { model) }\end{array}$ & 3.451 & 0.668 & 1.131 & 0.219 & 0.584 & 0.113 \\
\hline No bullying at school & 2.715 & 0.757 & 0.617 & 0.172 & 0.254 & 0.071 \\
\hline $\begin{array}{l}\text { Good relationship } \\
\text { with relatives }\end{array}$ & 2.891 & 0.727 & 0.781 & 0.197 & 0.302 & 0.076 \\
\hline Two-parent family & 2.955 & 0.727 & 0.811 & 0.200 & 0.297 & 0.073 \\
\hline High self-efficacy & 3.006 & 0.739 & 0.675 & 0.166 & 0.386 & 0.095 \\
\hline High family income & 3.087 & 0.749 & 0.689 & 0.167 & 0.346 & 0.084 \\
\hline High engagement & 3.186 & 0.711 & 0.906 & 0.202 & 0.391 & 0.087 \\
\hline Friends at school & 3.117 & 0.732 & 0.834 & 0.196 & 0.305 & 0.072 \\
\hline Low parenting stress & 3.189 & 0.750 & 0.719 & 0.169 & 0.346 & 0.081 \\
\hline Gender (female) & 3.032 & 0.695 & 0.921 & 0.211 & 0.411 & 0.094 \\
\hline $\begin{array}{l}\text { Good communication } \\
\text { skills }\end{array}$ & 3.065 & 0.675 & 1.023 & 0.225 & 0.450 & 0.100 \\
\hline $\begin{array}{l}\text { Support from close } \\
\text { friends }\end{array}$ & 3.276 & 0.701 & 0.925 & 0.198 & 0.469 & 0.101 \\
\hline $\begin{array}{l}\text { Good communication } \\
\text { with parents }\end{array}$ & 3.218 & 0.701 & 0.987 & 0.215 & 0.387 & 0.084 \\
\hline $\begin{array}{l}\text { Sense of classroom } \\
\text { community }\end{array}$ & 3.398 & 0.783 & 0.659 & 0.152 & 0.284 & 0.065 \\
\hline $\begin{array}{l}\text { Engagement in } \\
\text { school activities }\end{array}$ & 3.405 & 0.775 & 0.693 & 0.158 & 0.297 & 0.067 \\
\hline
\end{tabular}


Table 6. Likelihood of mental health difficulties by number of risk and promotive factors.

\begin{tabular}{llrrr}
\hline & & \multicolumn{2}{c}{ Mental Health Problem } \\
\cline { 3 - 5 } & & Unlikely & Possible & Probable \\
\hline Number of risk factors and \% of students in & $0(33 \%)$ & $88 \%$ & $10 \%$ & $2 \%$ \\
each category & $1(30.7 \%)$ & $82.6 \%$ & $10.9 \%$ & $6.5 \%$ \\
& $2(20.7 \%)$ & $67.8 \%$ & $16.1 \%$ & $16.1 \%$ \\
& $3(9.3 \%)$ & $50 \%$ & $21.4 \%$ & $28.6 \%$ \\
Number of promotive factors and \% of & $4(3.3 \%)$ & $40 \%$ & $20 \%$ & $40 \%$ \\
students in each category & $5(2.7 \%)$ & $25 \%$ & $25 \%$ & $50 \%$ \\
& $1(32.7 \%)$ & $40.8 \%$ & $24.5 \%$ & $34.7 \%$ \\
& $2(26 \%)$ & $57.8 \%$ & $22.2 \%$ & $20 \%$ \\
& $3(11.3 \%)$ & $66.7 \%$ & $20.8 \%$ & $12.5 \%$ \\
& $4(6 \%)$ & $76.5 \%$ & $17.6 \%$ & $5.9 \%$ \\
& $5(4 \%)$ & $100 \%$ & $11.1 \%$ & $0 \%$ \\
& & & $0 \%$ & $0 \%$ \\
\hline
\end{tabular}

$75 \%$ for those with five risk factors. This means that $36 \%$ of young primary school pupils have at least $32 \%$ chance of experiencing mental health difficulties, while $15 \%$ of pupils have at least $50 \%$ chance. Nine percent of pupils are at very high risk $(60 \%$ to $75 \%)$ of experiencing mental health problems.

The study also examined the cumulative effect of promotive factors on pupils' mental health. In $32.7 \%$ of the pupils, no promotive factor was present; one promotive factor was present in $30 \%$ of the participants, two factors in $16 \%$, three in $11.3 \%$, four in $6 \%$ and five in $4 \%$. Table 6 shows that the percentage of possible as well as probable mental health problems decreases steadily with every additional promotive factor $\left(X^{2}(10)=19.68\right.$, $p=0.032$ ). The percentage of pupils showing least signs of mental health difficulties is $59.2 \%$ in the group without any promotive factors, decreasing to $42.2 \%$ when one promotive factor is present and $33.3 \%$ in the case of two factors. The risk of mental health difficulties goes down to $23.5 \%$ in the presence of three factors, and to $11.1 \%$ when there are four factors. No pupil displayed mental health problems when there are five promotive factors. This means that one third of young primary school students have a $25 \%$ possibility of developing mental health problems and $35 \%$ the probability of mental health issues. On the other hand, having three or more promotive factors reduces significantly the probability of mental health problems: $11 \%$ of children (three promotive factors) have only a $6 \%$ probability of developing mental health issues, while $10 \%$ (four or more promotive factors) appear to be protected from mental health problems.

\section{Discussion}

The findings of this study suggest that as young children move from early to junior primary school, they are less likely to manifest SEBD and more likely to engage in prosocial behaviour, if they have good communication skills, high self-esteem and self-efficacy, good relationships with the teacher, peers and friends, play with and are supported by peers, are academically engaged and making good progress, with good teacher-parent communication and high parental academic expectations. They are likely to come from a two-parent, cohesive family with high quality time and low levels of conflict and parental stress, have good relationship with parents and siblings, are well behaved at home, and 
participate in local organisations. They attend classrooms with adequate resources and welltrained teachers, where pupils have a sense of community and participate actively in activities. The school they attend has a low level of bullying, good pupil behaviour, high pupil participation and collaboration, and active staff collaboration.

Considering the results of the multilevel analysis of both teachers' and parents' evaluations, it would seem that the strongest predictors for SEBD development in primary school, include school bullying, gender, poor communication skills, single-parent families, parenting stress, behaviour problems at home, low parental expectation, and poor relationships with teacher and peers. These are the pupils most at risk for developing SEBD, and the more risk factors they have, the more likelihood of difficulties in their social and emotional development, psychological well-being and academic success. Pupils with five or more of these negative factors have a $75 \%$ chance or more of developing SEBD and mental health difficulties in the early primary years. Risk factors tend to be cumulative, with one risk leading to other risks (Appleyard et al. 2005; Hawkins, Catalano, and Arthur 2002; Stoddard, Zimmerman, and Bauermeister 2012). The number of risks becomes more meaningful if we examine the nature or context of these factors and how they interact and 'add' together in impacting psychological well-being. Single-parent families for instance, are at risk of poverty, which is also linked to parental stress, less family time, lower parental academic expectations, and inadequate supervision, amongst others (Engle and Black 2008; McLanahan 2009).

Similarly the overall multilevel analysis findings suggest that the strongest predictors of prosocial behaviour across the years in the primary school, are low bullying at school, good relationships with the teacher, peers and family members, high self-efficacy and selfesteem, active engagement in lessons, and two-parent families with high income. The more such factors are present in pupils' lives, the more likely they are to enjoy psychological well-being and good mental health. For instance, the chance of having mental health problems when at least five promotive factors are present is $0 \%$, compared to $60 \%$ when no promotive factors are present. Increasing promotive factors will increase the likelihood of a healthy trajectory for vulnerable children, strengthening and maximizing their learning potential and their healthy relationships with those around them. These positives become the building blocks of well-being and resilience in childhood.

The strongest risk and promotive factors identified in the study are more related to the proximal classroom and home contexts in contrast to the more distal whole school and community contexts respectively. Micro processes such as relationships with teachers, peers, parents and friends, academic engagement, positive beliefs and expectations, healthy family dynamics and effective parenting, are particularly influential in the development of SEBD and prosocial behaviour. The strongest influences on children's learning, behaviour and development are the home and classroom contexts where children develop their closest relationships and attachments and spend most of their time (Benard 2004; Cefai 2008; Youngblade et al. 2007). Good parenting for instance, may counteract the negative impact of poverty, while supportive relationships and absence of parental discord with adults may help the child to cope with the impact of parental separation (Agaibi and Wilson 2005; Morrison Gutman et al. 2010). These findings underline the need for interventions which support the building of healthy, supportive and responsive classrooms and families, with particular attention to the relational processes operating in these two systems.

On the other hand, the distal factors help to strengthen and complement the healthy processes occurring in the classrooms and families. Healthy micro processes complemented and reinforced by macro processes, thus have a synergetic, value-added effect on pupils' development and behaviour. For instance, lack of bullying and good pupil 
behaviour at school, as well as staff teamwork and collaboration, have a positive impact on pupils' behaviour in the classroom (Cefai 2008; McLaughlin and Talbert 2006). Although community factors did not rank high on the list of significant predictors, other research underlines the importance of community investment and resources in preventing SEBD and promoting well-being, especially with older children and adolescents (Youngblade et al. 2007). Similarly although, family structure, family dynamics and parenting emerged as the key home predictors in contrast to the relatively weaker predictors such as locality, home language, ethnicity and socio-economic status, poverty, for instance, is still strongly related to SEBD in this study. Moreover, poverty may be related to other risk factors such as family and parenting stress, lack of quality time and poor supervision (Amato 2005; McLanahan 2009) as well as poor physical and mental health (Morrison Gutman et al. 2010; Schoon et al. 2012). Furthermore, the impact of family structure in the study may be partially explained by SES, since half of single parents in Malta are living on or below the poverty line (NSO 2011). Although factors such as locality, home language, and ethnicity, did not feature as significant predictors of either SEBD or prosocial behaviour, this may be due, at least in part, to other factors, such as sample representativeness and sample size. For instance, in view of the relatively small number of children and families in Malta who are non-Maltese, non-Christian and do not speak Maltese, these groups could not be adequately represented in the study's sample. Studies on the mental health of refugee children in Malta, for instance, suggest that such children are vulnerable to academic and mental health difficulties (Camilleri 2008; Calleja Ragonesi and Martinelli 2013; Galea 2013). Similarly in an earlier large scale study, children coming from relatively low socio-economic status (SES) regions were more likely to exhibit SEBD than children from more affluent regions (Cefai, Cooper, and Camilleri 2009).

One of the main implications of the study is the multifactorial dimension of risk and promotive factors, underlining the interaction between individual, peer, class, school, home and community factors in mental health promotion in childhood. The findings underline the need for systemic interventions which address the various contexts in children's lives, in line with the systemic perspective informing the study (Bronfenbrenner 1989). A multifaceted, systemic approach combining universal interventions with selective and indicated interventions in various social contexts such as home and school, would be the most effective approach to support the social and emotional health and well-being of children (Greenberg 2010; National Institute for Health and Clinical Excellence 2008; Weare and Nind 2011). It would also help to avoid inappropriate referrals to intervention and support services, while identifying the needs of children who may need within-school support as early as possible (National Institute for Health and Clinical Excellence 2008).

Our efforts to promote well-being and resilience in children need to be directed simultaneously at both risk reduction and the enhancement of protective and promotive factors, eliminating or reducing the risk factors children are exposed to, particularly chronic ones, while providing adequate support to help them develop their strengths and skills (Furlong et al. 2011; Kia Keating et al. 2011; Renshaw 2014). Moreover, we are more likely to be effective in resilience building if risk factors are countered within the same context, such as neutralizing school bullying by providing supervision and adult and peer support at school, or reducing the impact of marital discord by enhancing the child's relationships at home (Rutter 1999). However, particular systems still have a key role in helping to overcome the negative impact of other systems in children's lives. For instance, even in the case of children facing multiple risk factors or very unstable situations at 
home, the support and respite provided by schools and teachers can help to create an oasis of safety and stability and a platform for growth and success (O'Dougherty Wright and Masten 2005).

Another clear implication from the study is the need for early intervention as children's developmental is still fluid and taking shape. It identified various individual, peer, school and home factors which may lead to positive social, emotional and cognitive outcomes as pupils move from the early to the junior primary school. The literature has consistently shown that we are more likely to be effective in preventing SEBD and promoting psychological well-being and positive behaviour, if we start as early as possible when children are in preschool and the early primary school years (Domitrovich, Cortes, and Greenberg 2007; Denham, Brown, and Domitrovich 2010; Leerkes et al. 2008; McLaughlin and Clarke 2010).

The study investigated risk and promotive factors as the negative and positive ends of the same variable. Positing risk and promotive factors as separate constructs on the basis of the literature would have also made it possible to identify protective factors in the face of risk. Distinguishing between protective and promotive factor has clear implications for mental health promotion in school, providing a better understanding of the relationship between universal and targeted interventions, and delineating the level of intervention most likely to be most effective with particular factors (Furlong et al. 2011). Secondly, the risk and promotive predictors identified in the analysis were dependent on the list of factors measured in the study. For instance, factors such as marital conflict, parental psychopathology and child abuse, were not included in the study as they might have jeopardised parental consent and participation. Moreover, the positive behaviour and wellbeing dimension in the study assessed only prosocial behaviour; a broader well-being assessment may include self-efficacy, optimism, happiness and success, amongst others (Furlong et al. 2011; Renshaw 2014). Including additional risk, protective and promotive factors may help explain more variation in SEBD and prosocial behaviour, and provide more detailed analysis of the relationship between risk, protective and promotive factors and SEBD and well-being. The supplementary questionnaires which examined the factors related to SEBD and prosocial behaviour, may have benefitted from more rigorous psychometric evaluation, and more work needs to be done in constructing a more robust measurement of risk and protective factors in the local context.

\section{Conclusion}

This study was based on a relatively small sample in one particular cultural context which cautions about making unqualified generalisations across contexts and cultures. A larger, more representative sample would not only provide a stronger basis for the generalization of the findings, but would also make it possible to explore the impact of such predictive factors such as ethnicity, region and language as indicated earlier. It would also make it more possible to have a better understanding of the classroom and school effects on SEBD and well-being. This study was carried out three years after the first study with most of the pupils still attending the same school; in the next phases, we will be following the cohort at significant transitions in their school life, such as the primary to secondary and secondary-post secondary transitions. Mapping the interactions between the risk, promotive and protective factors at individual, peer, school, home and community levels in more precise ways across childhood and adolescence will make it possible to build more effective models of mental health promotion and resilience in childhood and adolescence. A developmental cascade perspective (Masten and Cicchetti 2010) will make it possible to 
map the trajectory of the various risk, protective and promotive factors at the various systemic levels, and how they increase the risks for SEBD or promote mental health, wellbeing and resilience as young children move into middle childhood and into adolescence.

\section{Acknowledgements}

This study was in part funded by the University of Malta.

\section{References}

Adelman, H. S., and L. Taylor. 2010. Mental Health in Schools: Engaging Learners, Preventing Problems and Improving Schools. Thousand Oaks, CA: Corwin.

Adi, Y., A. Killoran, K. Janmohamed, and S. Stewart-Brown. 2007. Systematic Review of the Effectiveness of Interventions to Promote Mental Wellbeing in Primary Schools: Universal Approaches which do not Focus on Violence or Bullying. London: National Institute for Clinical Excellence.

Agaibi, C. P., and J. E. Wilson. 2005. "Trauma, PTSD, and Resilience: A Review of the Literature." Trauma, Violence \& Abuse 6 (3): 195-216. doi:10.1177/1524838005277438

Amato, P. R. 2005. "The Impact of Family Formation Change on the Cognitive, Social, and Emotional Well-Being of the Next Generation." The Future of Children 15: 75-96. doi:10.1353/foc. 2005.0012

Appleyard, K., B. Egeland, M. van Dulmen, and L. Alan Sroufe. 2005. "When More is Not Better: The Role of Cumulative Risk in Child Behavior Outcomes." Journal of Child Psychology and Psychiatry 46 (3): 235-245. doi:10.1111/j.1469-7610.2004.00351.x

Arthur, M. W., J. S. Briney, J. D. Hawkins, R. D. Abbott, B. L. Brooke-Weiss, and R. F. Catalano. 2007. "Measuring Risk and Protection in Communities Using the Communities That Care Youth Survey." Evaluation and Program Planning 30 (2): 197-211. doi:10.1016/j. evalprogplan.2007.01.009

Avramidis, E., and B. Norwich. 2002. "Teachers' Attitudes Towards Integration/Inclusion: A Review of the Literature." European Journal of Special Needs Education 17 (2): 129-147. doi:10.1080/08856250210129056

Baker, P. H. 2005. "Managing Student Behaviour: How Ready are Teachers to Meet the Challenge?." American Secondary Education 33 (3): 50-67.

Battistich, V., E. Schaps, and N. Wilson. 2004. "Effects of an Elementary School Intervention on Students' "Connectedness" to School and Social Adjustment During Middle School." The Journal of Primary Prevention 24 (3): 243-262. doi:10.1023/B:JOPP.0000018048.38517.cd

Baumeister, R. F., J. D. Campbell, J. I. Krueger, and K. D. Vohs. 2003. "Does High Self-Esteem Cause Better Performance, Interpersonal Success, Happiness, or Healthier Lifestyles?." Psychological Science in the Public Interest 4: 1-44. doi:10.1111/1529-1006.01431

Benard, B. 2004. Resiliency: What We Have Learned. San Francisco, CA: WestEd.

Bradley, R. H., and R. F. Corwyn. 2007. "Externalizing Problems in Fifth Grade: Relations with Productive Activity, Maternal Sensitivity, and Harsh Parenting from Infancy Through Middle Childhood." Developmental Psychology 43: 1390-1401. doi:10.1037/0012-1649.43.6.1390

Bradley, R., J. Doolittle, and R. Bartolotta. 2008. "Building on the Data and Adding to the Discussion: The Experiences and Outcomes of Students with Emotional Disturbance." Journal of Behavioral Education 17: 4-23. doi:10.1007/s10864-007-9058-6

Bronfenbrenner, U. 1989. "Ecological Systems Theory." Annals of Child Development 6: 187-249.

Calleja Ragonesi, I., and V. Martinelli. 2013. "Somali Children in the Maltese Educational System." Malta Review of Educational Research 7 (2): 135-173.

Camilleri, J. 2008. "Do I Belong? Psychological Perspectives and Educational Considerations of Young Immigrants' School Experiences." Malta Review of Educational Research 6 (1): 64-79.

Cefai, C. 2008. Promoting Resilience in the Classroom. A Guide to Developing Emotional and Cognitive Skills. London: Jessica Kingsley Publishers.

Cefai, C., and P. Cooper. 2010. "Students Without Voices: The Unheard Accounts of Secondary School Students with Social, Emotional and Behaviour Difficulties." European Journal of Special Needs Education 25 (2): 183-198. doi:10.1080/08856251003658702 
Cefai, C., L. Camilleri, P. Cooper, and L. Said. 2011. "The Structure and Use of the Teacher and Parent Maltese Strengths and Difficulties Questionnaire." International Journal of Emotional Education 3 (1): 4-19.

Cefai, C., P. Cooper, and L. Camilleri. 2009. "Social, Emotional and Behaviour Difficulties in Maltese Schools." International Journal of Emotional Education 1 (1): 8-49.

Centre for Disease Control and Prevention. 2013. Mental Health Surveillance Among ChildrenUnited States 2005-2011. Centre for Disease Control and Prevention, USA.

Chanfreau, J., C. Lloyd, C. Byron, C. Roberts, R. Craig, D. De Feo, and S. McManus. 2013. Predicting Wellbeing. London: National Centre for Social Research.

Cole, T., H. Daniels, and J. Visser. 2005. "The Mental Health Needs of Pupils with EBD." In Child and Adolescent Mental Health Services, edited by R. Williams, and M. Kerfoot, Oxford: Oxford University Press.

Colman, I., J. Murray, R. A. Abbott, B. Maughan, D. Kuh, T. J. Croudace, and P. B. Jones. 2009. "Outcomes of Conduct Problems in Adolescence: 40 Year Follow-up of National Cohort." British Medical Journal 338: a2981. doi:10.1136/bmj.a2981

Cooper, P., and B. Jacobs. 2011. From Inclusion to Engagement. Chichester: Wiley.

Darling, N. 1999. Parenting Style and its Correlates. ERIC Digest EDO-PS-99-3, Clearinghouse on Elementary and Early Childhood Education. University of Illinois, Illinois.

DataPrev Project. 2011. "Mental health prevention in educational settings." Accessed June 12013. from http://www.dataprevproject.net/Educational_Settings.

Davis-Kean, P. E. 2005. "The Influence of Parent Education and Family Income on Child Achievement: The Indirect Role of Parental Expectations and the Home Environment." Journal of Family Psychology 19 (2): 294-304. doi:10.1037/0893-3200.19.2.294

Denham, S. A., C. Brown, and C. E. Domitrovich. 2010. "Plays Nice with Others': SocialEmotional Learning and Academic Success." Early Education and Development 21: 652-680. doi:10.1080/10409289.2010.497450

Desforges, C., and A. Abouchaar. 2003. The Impact of Parental Involvement, Parental Support and Family Education on Pupil Achievement and Adjustment: A Literature Review. London: Department for Education and Skills.

Domitrovich, C. E., R. Cortes, and M. T. Greenberg. 2007. "Improving Young Children's Social and Emotional Competence: A Randomized Trial of the Preschool "PATHS" Curriculum." The Journal of Primary Prevention 28 (2): 67-91. doi:10.1007/s10935-007-0081-0

Engle, P. L., and M. M. Black. 2008. "The Effect of Poverty on Child Development and Educational Outcomes." Annals of the New York Academy of Sciences 1136: 243-256. doi:10.1196/ annals.1425.023

Farrell, P., and F. Polat. 2003. "The Long Term Impact of Residential Provision for Pupils with Emotional and Behavioural Difficulties." European Journal of Special Needs Education 18 (3): 277-292. doi:10.1080/0885625032000120189

Farrell, P., and N. Humphrey. 2009. "Improving Services for Pupils with Social, Emotional and Behaviour Difficulties: Responding to the Challenge." International Journal of Emotional Education 1 (1): 64-82.

Fergusson, D. M., L. J. Horwood, and E. M. Ridder. 2005. "Show Me the Child at Seven: The Consequences of Conduct Problems in Childhood for Psychosocial Functioning in Adulthood." Journal of Child Psychology and Psychiatry 46: 837-849. doi:10.1111/j.14697610.2004.00387.x

Ford, T., S. Collishaw, H. Meltzer, and R. Goodman. 2007. "A Prospective Study of Childhood Psychopathology: Independent Predictors of Change Over Three Years." Social Psychiatry and Psychiatric Epidemiology 42 (12): 953-961. doi:10.1007/s00127-007-0272-2

Furlong, M. J., J. D. Sharkey, M. Quirk, and E. Dowdy. 2011. "Exploring the Protective and Promotive Effects of School Connectedness on the Relation Between Psychological Health Risk and Problem Behaviors/Experiences." Journal of Educational and Developmental Psychology 1: 18-34. doi:10.5539/jedp.v1n1p18

Galea, S. 2013. "Educating the Migrant Girl. A Politics of Difference." Malta Review of Educational Research 7 (2): 241-259.

Goodman, R. 1997. "The Strengths and Difficulties Questionnaire: A Research Note." Journal of Child Psychology and Psychiatry 38: 581-586. doi:10.1111/j.1469-7610.1997.tb01545.x

Goodman, R., D. Renfrew, and M. Mullick. 2000. "Predicting Type of Psychiatric Disorder from Strengths and Difficulties Questionnaire (SDQ) Scores in Child Mental Health Clinics in 
London and Dhaka." European Child Adolescent Psychiatry 9: 129-134. doi:10.1007/ s007870050008

Greenberg, M. T. 2010. "School-based Prevention: Current Status and Future Challenges." Effective Education 2: 27-52.

Griffin, K. W., G. J. Botvin, L. M. Scheier, T. Diaz, and N. L. Miller. 2000. "Parenting Practices as Predictors of Substance Use, Delinquency, and Aggression Among Urban Minority Youth: Moderating Effects of Family Structure and Gender." Psychology of Addictive Behaviors 14: 174-184. doi:10.1037/0893-164X.14.2.174

Guerra, N., and Bradshaw, C.P. 2008. "Linking the Prevention of Problem Behaviors and Positive Youth Development: Core Competencies for Positive Youth Development and Risk Prevention." New Directions for Child and Adolescent Development 2008: 1-17. doi:10.1002/ cd.225

Gutman, L. M., and J. Brown. 2008. The Importance of Social Worlds: An Investigation of Peer Relationships. Centre for the Wider Benefits of Learning. London: Institute of Education.

Gutman, L. M., and L. Feinstein. 2008. Parenting Behaviours and Children's Development from Infancy to Early Childhood: Changes, Continuities, and Contributions. Centre for the Wider Benefits of Learning. London: Institute of Education.

Hamre, B. K., and R. C. Pianta. 2001. "Early Teacher-Child Relationships and the Trajectory of Children's School Outcomes through Eighth Grade." Child Development 72 (2): 625-638. doi:10.1111/1467-8624.00301

Hawkins, J. D., R. F. Catalano, and M. W. Arthur. 2002. "Promoting Science-Based Prevention in Communities." Addictive Behaviors 27 (6): 951-976. doi:10.1016/S0306-4603(02)00298-8

Hysing, M., I. Elgen, C. Gillberg, S. A. Lie, and A. J. Lundervold. 2007. "Chronic Physical Illness and Mental Health in Children. Results from a Large-Scale Population Study." Journal of Child Psychology and Psychiatry 48: 785-792. doi:10.1111/j.1469-7610.2007.01755.x

Jull, S. K. 2008. "Emotional and Behavioural Difficulties (EBD): The Special Educational Need Justifying Exclusion." Journal of Research in Special Educational Needs 8 (1): 13-18. doi:10.1111/j.1471-3802.2008.00097.x

Kalambouka, A., P. Farrell, A. Dyson, and I. Kaplan. 2007. "The Impact of Placing Pupils with Special Educational Needs in Mainstream Schools on the Achievement of their Peers." Educational Research 49: 365-382. doi:10.1080/00131880701717222

Kia-Keating, M., E. Dowdy, M. Morgan, and G. G. Noam. 2011. "Protecting and Promoting: An Integrative Conceptual Model for Healthy Development of Adolescents." Journal of Adolescent Health 48: 220-228. doi:10.1016/j.jadohealth.2010.08.006

Leerkes, E. M., M. Paradise, M. O’Brien, S. D. Calkins, and G. Lange. 2008. "Emotion and Cognition Processes in Preschool Children." Merrill-Palmer Quarterly 54: 102-124. doi:10.1353/mpq.2008.0009

Leventhal, T., and J. Brooks-Gunn. 2000. "The Neighborhoods they Live In: The Effects of Neighborhood Residence on Child and Adolescent Outcomes." Psychological Bulletin 126: 309-337. doi:10.1037/0033-2909.126.2.309

Linnenbrink, E. A., and P. R. Pintrich. 2003. "The Role of Self-Efficacy Beliefs in Student Engagement and Learning in the Classroom." Reading and Writing Quarterly: Overcoming Learning Difficulties 19 (2): 119-137. doi:10.1080/10573560308223

Loeber, R., and D. Hay. 1997. "Key Issues in the Development of Aggression and Violence from Childhood to Early Adulthood." Annual Review of Psychology 48 (1): 371-410. doi:10.1146/ annurev.psych.48.1.371

MacBeath, J. 2006. "Finding a Voice, Finding Self." Educational Review 58 (2): 195-207. doi:10.1080/00131910600584140

Masten, A. S. and Cicchetti, D. (Eds) 2010. "Developmental Cascades [Special Issue, Parts 1 and 2]." Development and Psychopathology 22 (3): 491-495. doi:10.1017/S0954579410000222

Masten, A. S. 2001. "Ordinary Magic: Resilience Processes in Development." American Psychologist 56: 227-238. doi:10.1037/0003-066X.56.3.227

McLanahan, S. 2009. "Fragile Families and the Reproduction of Poverty." The ANNALS of the American Academy of Political and Social Science 621: 111-131. doi:10.1177/ 0002716208324862

McLaughlin, C., and B. Clarke. 2010. "Relational Matters: A Review of the Impact of School Experience on Mental Health in Early Adolescence." Educational and Child Psychology. Special Issue: In-School Relationships and their Outcomes 27: 91-103. 
McLaughlin, M., and J. Talbert. 2006. Building School-Based Teacher Learning Communities. New York, NY: Teachers College Press.

Morrison Gutman, L., J. Brown, R. Akerman, and P. Obolenskaya. 2010. Change in Wellbeing from Childhood to Adolescence: Risk and Resilience. London: Institute of Education, University of London.

National Institute for Health and Clinical Excellence. 2008. Promoting Children's Social and Emotional Wellbeing in Primary Education. London: National Health Service.

NSO. 2011. "International Day of Families." Malta, National Office of Statistics, May 13.

O'Dougherty Wright, M. and A. S. Masten. 2005. "Resilience Process in Development." In Handbook of Resilience in Children, S. Goldstein, and R. B. Brooks (eds.). New York: Springer.

O'Regan, F. 2011. "Exclusion from School and ADHD." International Journal of Emotional Education 2 (2): 3-18.

Ofsted. 2007. "Developing social, emotional and behavioural skills in secondary schools." Accessed June 1 2013. http://www.ofsted.gov.uk

Parsons, C., R. Godfrey, K. Howlett, C. Hayden, and T. Martin. 2001. "Excluding Primary School Children - the Outcomes Six Years On.” Pastoral Care in Education 19 (4): 4-15. doi:10.1111/ 1468-0122.00206

Renshaw, T. L. 2014. “Covitality: A Synergistic Conception of Adolescents' Mental Health.” In Handbook of Positive Psychology in the Schools. 2nd ed., edited by M. J. Furlong, R. Gilman, and E. S. Huebner, New York, NY: Routledge/Taylor \& Francis.

Rose, W., J. Aldgate, M. McIntosh, and H. Hunter. 2009. "High-Risk Children with Challenging Behaviour: Changing Directions for Them and Their Families." Child and Family Social Work 14: 178-188. doi:10.1111/j.1365-2206.2009.00622.x

Rutter, M. 1999. "Resilience Concepts and Findings: Implications for Family Therapy." Journal of Family Therapy 21: 119-144. doi:10.1111/1467-6427.00108

Schoon, I., E. Jones, H. Cheng, and B. Maughan. 2012. "Family Hardship, Family Instability, and Cognitive Development." Journal of Epidemiology \& Community Health 66 (8): 716-722. doi:10.1136/jech.2010.121228

Seligman, M., R. M. Ernst, J. Gillham, K. Reivich, and M. Linkins. 2009. "Positive Education: Positive Psychology and Classroom Interventions." Oxford Review of Education 35 (3): 293-311. doi:10.1080/03054980902934563

Stoddard, S. A., M. A. Zimmerman, and J. A. Bauermeister. 2012. "A Longitudinal Analysis of Cumulative Risks, Cumulative Promotive Factors, and Adolescent Violent Behavior." Journal of Research on Adolescence 22 (3): 542-555. doi:10.1111/j.1532-7795.2012.00786.x

Weare, K., and M. Nind. 2011. Promoting Mental Health of Children and Adolescents through Schools and School Based Intervention Evidence Outcomes School based Interventions Report of Workpackage Three of the Dataprev Project. UK: University of Southampton.

Werner, E., and R. Smith. 1992. Overcoming the Odds: High-Risk Children from Birth to Adulthood. New York: Cornell University Press.

World Health Organisation. 2011. "Mental Health: Strengthening Mental Health Promotion." Accessed June 1 2013. http://www.who.int/mediacentre/factsheets/fs220/en/

Youngblade, L. M., C. Theokas, J. Schulenberg, L. Curry, I. C. Huang, and M. Novak. 2007. "Risk and Promotive Factors in Families, Schools, and Communities: A Contextual Model of Positive Youth Development in Adolescence." Pediatrics 119: SS47-SS53. doi:10.1542/peds.2006$2089 \mathrm{H}$ 